\title{
Microwave Plasma Treatment for Catalyst Preparation: Application to Alumina Supported Silver Catalysts for SCR NO by Ethanol
}

\author{
Marjorie Foix $^{1,2}$, Cédric Guyon ${ }^{1}$, Michael Tatoulian ${ }^{1}$, Patrick Da Costa ${ }^{2 *}$ \\ ${ }^{1}$ Chimie Paristech, LGPPTS, Plasma Chemical Engineering Laboratory, Paris, France \\ ${ }^{2}$ UPMC Paris 6, Sorbonne University, IJLRA, JEan Le Rond d'Alembert Institute, Saint Cyr L'Ecole, France \\ Email: " patrick.da_costa@upmc.fr
}

Received January 12, 2013; revised March 5, 2013; accepted April 12, 2013

Copyright (C) 2013 Marjorie Foix et al. This is an open access article distributed under the Creative Commons Attribution License, which permits unrestricted use, distribution, and reproduction in any medium, provided the original work is properly cited.

\begin{abstract}
Thermal treatment either in the presence of oxygen (calcination) or of a reducing agent (reduction) result is all the time a key issue within the preparation of a catalyst. In this work, a microwave plasma treatment was chosen as an alternative to typical calcinations, because it is a more energy efficient process. Thus, a Microwave Fluidized Bed Plasma reactor (MFBP) was employed in catalyst synthesis process under different gas compositions, such as argon and argon/oxygen mixtures over $\gamma$-alumina supported silver catalysts, which are generally used for selective reduction of $\mathrm{NO}_{\mathrm{x}}$ by ethanol. After the first catalytic tests performed in the presence of plasma treated catalyst, it can be concluded that plasma treatment process represents an interesting alternative to conventional calcination during catalyst synthesis, resulting in a more sustainable process, moreover in view of its industrial application. In order to understand the particular effect of plasma treatment, the catalysts submitted to this treatment were carefully characterized by means of thermo gravimetric analysis (TGA), differential thermal analysis (DTA) and UV-VIS-NIR.
\end{abstract}

Keywords: Microwave Plasma; Fluidized Bed Reactor; Catalyst Synthesis; Silver Catalyst; $\mathrm{NO}_{\mathrm{x}}$ Reduction

\section{Introduction}

All around the world, the major chemical engineering processes are catalytic processes. Most the used catalysts are heterogeneous supported catalysts. An effective catalyst is generally described to have a high specific surface area in which the catalytic phase ishighly dispersed. In commercial form, the final catalyst should also possess high mechanical strength and resistance to high temperatures [1].

Conventional synthesis of supported catalysts comprises four main steps, namely: 1) impregnation of the active phase; 2) maturation; 3) drying; 4) thermal activation such as calcination or reduction. Nowadays, the lack of an accurate control of some of these operations results in catalytic preparation procedures, which may be far from perfect [2,3].

In the field of catalysis, Plasma technologies have been found to be a solution in order to improve the activeity or the stability of the processes [4]. Low-tem-

"Corresponding author. perature plasmas are often used for surface processes like cleaning, activating or coating. Moreover, plasma technologies have been used within different processes as a way of activating many molecules involved, enhancing the global reaction kinetics. In example, Kiyokawa et al. [5] decomposed nitric oxide, which is one of the most notorious atmospheric pollutants, in the presence of atmospheric pressure plasma. Additionally, this method is also a promising physical tool for biological decontamination and sterilization. Deng et al. [5] described a glow discharge plasma jet and its applications in protein destruction by using a dielectric barrier discharge arrangement. Kolb et al. [6] demonstrated that an air micro plasma jet can effectively treat yeast infection on skin.

Other authors have proposed to use plasma technologies in the synthesis process of the catalysts [7-11]. In general, there are three main trends in catalyst preparation using plasma technologies, such as: plasma chemical synthesis of ultrafine particle catalysts [7-9], plasma assisted deposition of catalytically active compounds on various supports $[7,11]$ and plasma enhanced preparation or plasma modification of catalysts [9]. Vissokov et al. [7] 
presented a synthesis of a $\gamma-\mathrm{Al}_{2} \mathrm{O}_{3}$ from elementary aluminium and oxygen under plasma jet. The condensedphase catalyst preparation can be carried out in both equilibrium and non-equilibrium plasma conditions. Rouleau et al. [9] presented a synthetic catalytic system prepared by plasma discharge spark between two metal electrodes immersed in a light hydrocarbon medium. Xia et al. [8] presented the preparation of palladium catalysts supported on structured carbon nanotubes. It was shown that the oxygen-containing groups introduced by the plasma treatment on the surface are essential to achieve a high Pd loading. There are two techniques regarding plasma enhanced preparation or plasma modification of catalyst: plasma heat treatment and plasma chemical treatment. Plasma heat treatment is carried out to replace the catalyst thermal calcination [11]. On the other hand, one of the important applications of plasma chemical treatment is the modification of zeolite acidity.

Within plasma technologies, cold plasma process particularly stands out as a considerably efficient and practical method for the selective modification of the surface of raw materials, avoiding any change in their properties. Therefore, plasma can be employed in the functionalization of several materials and activation of their surface, depending on the nature of the gas phase and experimental treatment conditions. Since, most of the time the raw materials are in powder form, Fluidized bed reactors (FBR) offer the possibility of achieving homogenous treatment as well as an accurate control of the gas-solid particles heat transfert rates $[11,12]$. In the literature, the plasma technology was already used after catalyst preparation in order to modify the raw material $[13,14]$. A recent work showed that radio frequency plasma treated catalysts led to higher efficiency in $\mathrm{NO}_{\mathrm{x}}$ abatement for methane SCR of $\mathrm{NO}_{\mathrm{x}}$ than classical calcined catalysts [15]. The aim of our work is to prepare a catalyst dedicated to $\mathrm{NO}_{\mathrm{x}}$ abatement in mobile sources using plasma during the synthesis process. In this context, a silverbased catalyst was chosen since the studied reaction is Ethanol SCR [16].

Upon preparation of different catalysts, the efficiency of fluidized bed plasma treatment of $\mathrm{Ag} / \mathrm{Al}_{2} \mathrm{O}_{3}$ catalysts activation has been compared versus classical calcination in air at $500^{\circ} \mathrm{C}$. Different techniques have been used for physic-chemical and activity characterization, such as temperature programmed surface reaction (TPSR), thermogravimetric analysis (TGA) and differential thermal analysis (DTA), transmission electron microscopy (TEM) coupled by energy dispersive spectroscopy (EDS), UVVis spectroscopy. In this study, we have also shown that the role of the microwave plasma treatment time plays a definitive role in the efficiency of alumina supported silver based materials.

\section{Experimental}

\subsection{Catalyst Preparation and Microwave Plasma Fluidized Bed Reactor}

A classical excess solution impregnation was chosen as synthesis method for catalyst preparation. Thus, $\mathrm{g}-\mathrm{Al}_{2} \mathrm{O}_{3}$ spheres of $600 \mu \mathrm{m}\left(170 \mathrm{~m}^{2} \cdot \mathrm{g}^{-1}\right)$, chosen as a support in order to obtain a homogeneous fluidization and to avoid loss of small particles in the pumping system, were introduced in an aqueous solution containing silver nitrate. The silver loading was fixed at $2.5 \mathrm{wt} \%$ because this loading was found to be optimal for such catalytic application [17]. Then, the excess of solution was removed by the means of evaporation at $60^{\circ} \mathrm{C}$ under reduced pressure as reported elsewhere [17]. Then, the as-prepared catalysts were dried at $120^{\circ} \mathrm{C}$ overnight, prior to the two different treatment processes:

1) Classical calcination in oven under synthetic air $\left(20 \% \mathrm{O}_{2} / 80 \% \mathrm{~N}_{2}\right)$ at $500^{\circ} \mathrm{C}$ for $2 \mathrm{~h}$ with a heating rate of $10^{\circ} \mathrm{C} \cdot \mathrm{min}^{-1}$;

2) Microwave Fluidized Bed Plasma treatment in Fluidized bed reactors (FBR) reactor.

As reported in Figure 1, the Microwave Plasma Fluidized Bed Reactor (MPFBR) consists of a cylindrical glass tube of $30 \mathrm{~mm}$ inner diameter and $600 \mathrm{~mm}$ length.

After drying, impregnated alumina supported silver catalysts (r: $795 \mathrm{~kg} \cdot \mathrm{m}^{-3}$, mean-diameter of particles: 600 $\mu \mathrm{m})$ were fluidized using the pre-treament gases.

Moreover, we worked at the minimum fluidization conditions determined from the pressure drop versus gas flow rate [18]. All the characteristics of the reactor are described elsewhere [11].

The plasma is created as the following: two external electrodes were placed at the level of the fluidized bed and the plasma was maintained by a Microwave energy source using a Sairem generator (power range $0-300 \mathrm{~W}$ ). A wattmeter was used in order to follow incident and reflected powers, its characteristics are reported elsewhere [19]. The different plasma parameters used for the final treatment of $\mathrm{Ag} / \mathrm{Al}_{2} \mathrm{O}_{3}$ catalysts are listed in Table 1. The samples were denoted MW-X, in which X corresponds to a specific microwave treatment time or gas mixture.

\subsection{Physical and Chemical Catalysts Characterization}

Scanning electron microscopy (SEM) was performed on a JEOL JMS 6400 coupled with an energy dispersive spectrophotometer (EDS) analyser link EXL. For the transmission electron microscopy (TEM), the samples were deposited on a carbon film supported on a copper grid in dry conditions in order to avoid metallic silver particles [20]. Ultraviolet-visible diffuse reflectance spectra (UV-vis DRS) were collected using a spectrophotometer 


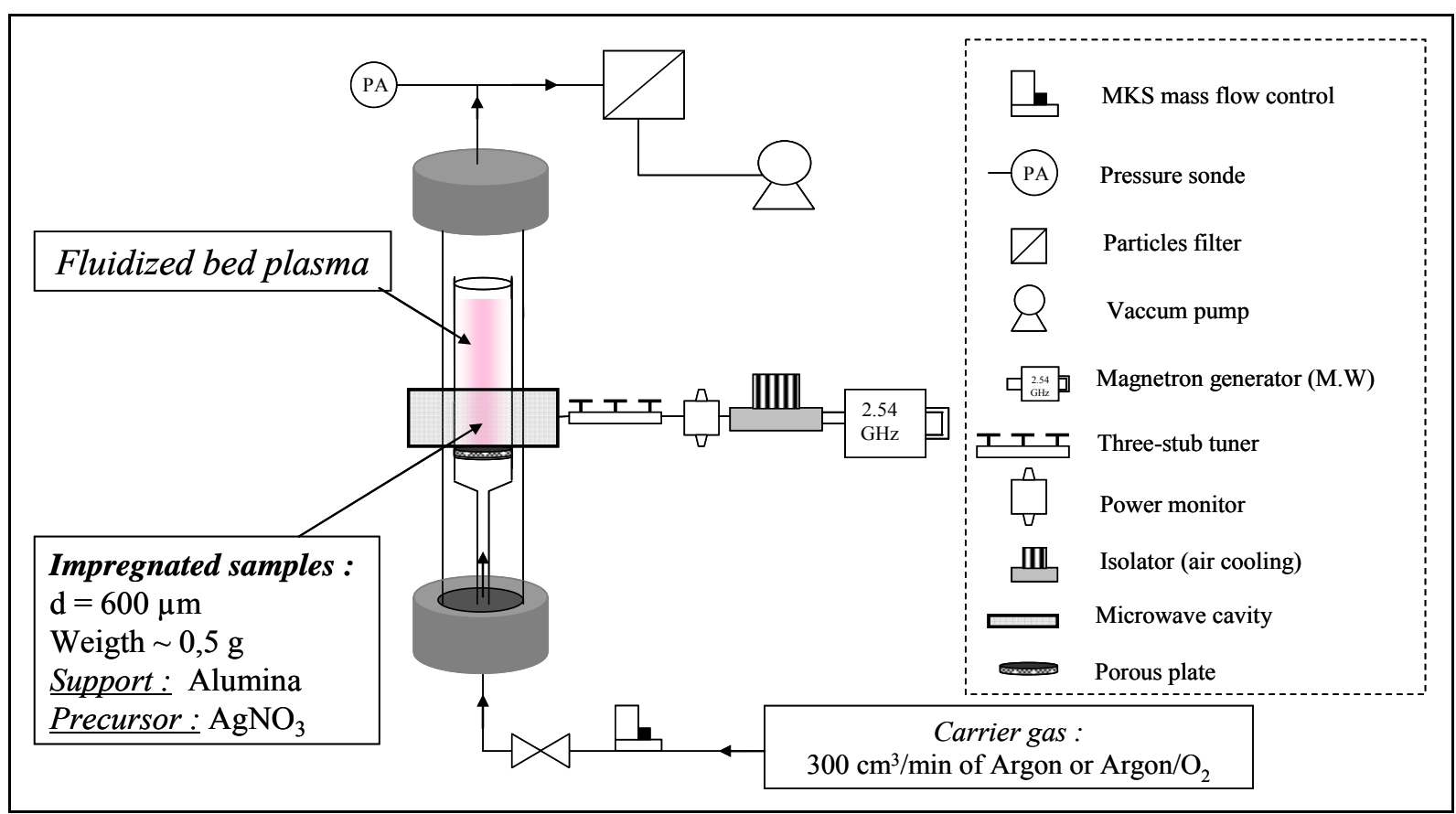

Figure 1. Experimental set-up of the fluidized bed reactor (FBR) used for the plasma surface treatment of powders.

Table 1. Experimental parameters used during the microwave plasma treatment.

\begin{tabular}{|c|c|c|c|c|c|c|}
\hline \multirow{2}{*}{ Experimental parameters } & \multicolumn{6}{|c|}{ Catalyst code } \\
\hline & M.W-1 & M.W-2 & M.W-3 & M.W-4 & M.W-5 & M.W-6 \\
\hline Argon flow rate $\left(\mathrm{cm}^{3} / \mathrm{min}\right)$ & 300 & 300 & 300 & 240 & 300 & 240 \\
\hline Oxygen flow rate $\left(\mathrm{cm}^{3} / \mathrm{min}\right)$ & 0 & 0 & 0 & 60 & 0 & 60 \\
\hline Pressure (mbar) & 0.70 & 0.70 & 0.70 & 0.70 & 0.70 & 0.70 \\
\hline Electrical source & M.W 2.45 & M.W 2.45 & M.W 2.45 & M.W 2.45 & M.W 2.45 & M.W 2.45 \\
\hline Plasma power (Watt) & 500 & 500 & 500 & 500 & 800 & 800 \\
\hline Treatment time (min) & 10 & 30 & 60 & 30 & 30 & 30 \\
\hline
\end{tabular}

(Lambda 40, Perkin-Elmer) equipped with a diffuse reflectance attachment (DRA) (Harrick). Spectra were collected at room temperature in air in the range of 190 $500 \mathrm{~nm}$ with a resolution of $2 \mathrm{~nm}$. As a reference we used a compressed pellet of polytetrafluoroethylene (Teflon) powder, which is superior to the conventional $\mathrm{BaSO}_{4}$ layer with regard to both spectral smoothness and reproducibility [21]. X-ray diffraction patterns were obtained on a Seifert XRD 3000 radiation. We carried out $t$ spectrometer using $\mathrm{Cu}$ Khermogravimetric analyses (TGA) coupled mass spectrometry from Room Temperature (RT) up to $800^{\circ} \mathrm{C}$ in $80 \% \mathrm{~N}_{2} / 20 \% \mathrm{O}_{2}$ mixture $\left(100 \mathrm{~cm}^{3} \cdot \mathrm{min}^{-1}\right.$, $30 \mathrm{mg}$ of catalyst).

\subsection{Selective Reduction of $\mathrm{NO}_{\mathrm{x}}$ by Ethanol}

The catalytic runs of the $\mathrm{NO}_{\mathrm{x}}$ reduction by ethanol
$(\mathrm{EtOH})$ were performed in a fixed-bed flow reactor $(10$ mm inner diameter) by flowing 500 ppm NO, 2500 ppm $\mathrm{EtOH}$, and $10 \mathrm{vol} \% \mathrm{O}_{2}$ in $\mathrm{Ar}$ as carrier gas with a flow rate of $184 \mathrm{~cm}^{3} \cdot \mathrm{min}^{-1}$ using $0.045 \mathrm{~g}$ of sample corresponding to a Gas Hourly Space Velocity of $190,000 \mathrm{~h}^{-1}$. Temperature programmed surface reaction (TPSR) was carried out at a heating rate of $10^{\circ} \mathrm{C} \cdot \mathrm{min}^{-1}$ up to $500^{\circ} \mathrm{C}$. In order to study the reaction in steady-state conditions, isothermal steady-state reaction study was performed subsequently, from $500^{\circ} \mathrm{C}$ to $250^{\circ} \mathrm{C}$, by steps of $50^{\circ} \mathrm{C}$, to avoid adsorption/desorption processes. At each temperature to reach the steady state and thus to evaluate the $\mathrm{NO}_{\mathrm{x}}$ conversion into $\mathrm{N}_{2}$, the temperature was maintained for 1 h. The temperature was increased up to $500^{\circ} \mathrm{C}$. The products of the reaction were quantified by the mean of various analyzers: a micro-chromatograph Varian for $\mathrm{N}_{2}$ 
production, an infrared Ultramat Siemens detector for $\mathrm{CO}, \mathrm{CO}_{2}$, a chemiluninescence Ecophysics detector was used for $\mathrm{NO}_{\mathrm{x}}$ detection ( $\mathrm{NO}$ and $\mathrm{NO}_{2}$ ); the other compounds were followed by mass spectrometry (MKS Instrument). Only the ethanol was detected by mass spectropmetry during our experimental tests, thus no oxygenated intermediates have been evidenced.

\section{Results and Discussion on the $\mathrm{Ag} / \mathrm{Al}_{2} \mathrm{O}_{3}$}

\subsection{A Sustainable Plasma FBR Treatment versus a Classical Thermal Treatment}

The classical calcination was carried out under air at $500^{\circ} \mathrm{C}$ for 2 hours leading to a non-sustainable process due to use high temperatures and the consumption of industrial air. In our FBR system, the process takes place at low temperature. In the FBR system, the temperature of gas was found around $127^{\circ} \mathrm{C} \pm 50^{\circ} \mathrm{C}$. In order to verify this value, we used powders materials knowing their melting point precisely, these samples references, very sensitive to a change of temperature, were used to generally calibrate a bench of Kofler. Table 2 indexes the samples which were placed on sintered engine during a M.W plasma treatment to determine the temperature range. For a microwave plasma treatment (a power 500 Watt, a pressure of 0.70 mbar and an argon flow of 300 $\mathrm{cm}^{3} \cdot \min ^{-1}$ ), the Azobetol sample melts on the contrary to the Benzil sample. Thus we can admit that the temperature interns our plasma M.W lies between $68^{\circ} \mathrm{C}$ and $95^{\circ} \mathrm{C}$. This value corresponds so that we found by calculations. Thus, the temperature of plasma is definitely lower than the calcination temperature $\left(500^{\circ} \mathrm{C}\right)$.

\subsection{Influence of Plasma Treatment on the Steady-State Activity of the Catalysts in the SCR of $\mathrm{NO}_{\mathrm{x}}$ in the Presence of Ethanol}

\subsubsection{Effect of Plasma Treatment Time}

The reaction of $\mathrm{NO}_{\mathrm{x}}$ by ethanol was carried out on all

Table 2. Range of samples reference.

\begin{tabular}{cc}
\hline Material name & Melting point $\left({ }^{\circ} \mathbf{C}\right)$ \\
\hline Azobenzol & 68.0 \\
Benzil & 95.0 \\
Acetanilide & 114.5 \\
Phenacetin & 134.5 \\
Benzanilide & 163.0 \\
Salophen & 191.0 \\
Dicyandiamide & 210.0 \\
Saccharin & 228.0 \\
\hline
\end{tabular}

pre-treated catalyst (MW-X and calcined ones). In steady-state conditions, in isothermal range, the $\mathrm{NO}_{\mathrm{x}}$ reduction efficiency of alumina supported silver catalysts increased with the temperature, reaching a maximum around $400^{\circ} \mathrm{C}$ for all samples. Figure 2(a) compares different microwave plasma treatment with $500 \mathrm{~W}$ under argon as carrier gas, in which only the processing time varies. All the microwave plasma-treated catalysts show better conversion that the sample without treatment. We observe that the processing time of $30 \mathrm{~min}$ (M.W-2) lends on all the range of temperature to a higher $\mathrm{NO}_{\mathrm{x}}$ conversion compared to the calcination. Thus, at $300^{\circ} \mathrm{C}$, $55 \%$ of $\mathrm{NO}_{\mathrm{x}}$ conversion is observed on $\mathrm{M} . \mathrm{W}-2$ vs. $43 \%$ on Calcined sample and at $400^{\circ} \mathrm{C}, 95 \%$ of $\mathrm{NO}_{\mathrm{x}}$ conversion is obtained with M.W-2 catalyst whereas only $80 \%$ of $\mathrm{NO}_{\mathrm{x}}$ conversion is achieved with the calcined sample. We can also notice that the sample treated during $1 \mathrm{~h}$ (M.W-3) reaches high conversions from $250^{\circ} \mathrm{C}$ to $370^{\circ} \mathrm{C}$ such as treatment M.W-2. Then from $370^{\circ} \mathrm{C}$ to $520^{\circ} \mathrm{C}$, a decrease of $\mathrm{NO}_{\mathrm{x}}$ activity is observed. We can suppose that this longer treatment generated reactions at the surface and modified the active sites. Similar result has already been reported for methane $\mathrm{SCR}$ of $\mathrm{NO}_{\mathrm{x}}$ on palladium based catalysts [11] using another plasma system. The microwave plasma treatment of 10 min leads to intermediate conversions in comparison with the sample without treatment and the calcined sample.

\subsubsection{Effect of Power of Plasma on the Catalytic Activity}

On Figure 2(b), the effect of the power on catalyst was presented. An increase of power from $500 \mathrm{~W}$ and $800 \mathrm{~W}$ for a similar treatment time of $30 \mathrm{~min}$, does not affect the $\mathrm{NO}_{\mathrm{x}}$ conversion on silver based catalysts. Similar effect has been found with 10 and 60 min respectively (Figure not shown). Thus, one can suppose that similar active sites remain on both samples.

\subsubsection{Influence of Gas Composition of the Plasma}

Figure 2(c) compares plasma treatment of $500 \mathrm{~W}$ during 30 min under two different carrier gases: argon alone (M.W-2) and 20\% oxygen/argon (M.W-4). On the two M.W. plasma treated show a better conversion than that obtained on the no-treated sample and on the calcined one. The oxygen brought in the plasma treatment does not have a particular influence on this catalytic system $\mathrm{Ag} / \mathrm{Al}_{2} \mathrm{O}_{3}$ for $500 \mathrm{~W}$. However, with higher power $(800$ W) (Figure 2(d)) we notice a catalyst deactivation because oxygen recombines with higher power creating unfavourable reactions [22]. All the plasma treated samples lead to higher $\mathrm{NO}_{\mathrm{x}}$ conversion than the untreated sample. In view of the results obtained to obtained results, the M.W-2 plasma treatment is most effective. Similar results have been obtained using another kind of plasma generator such as radio frequency generator [11]. 


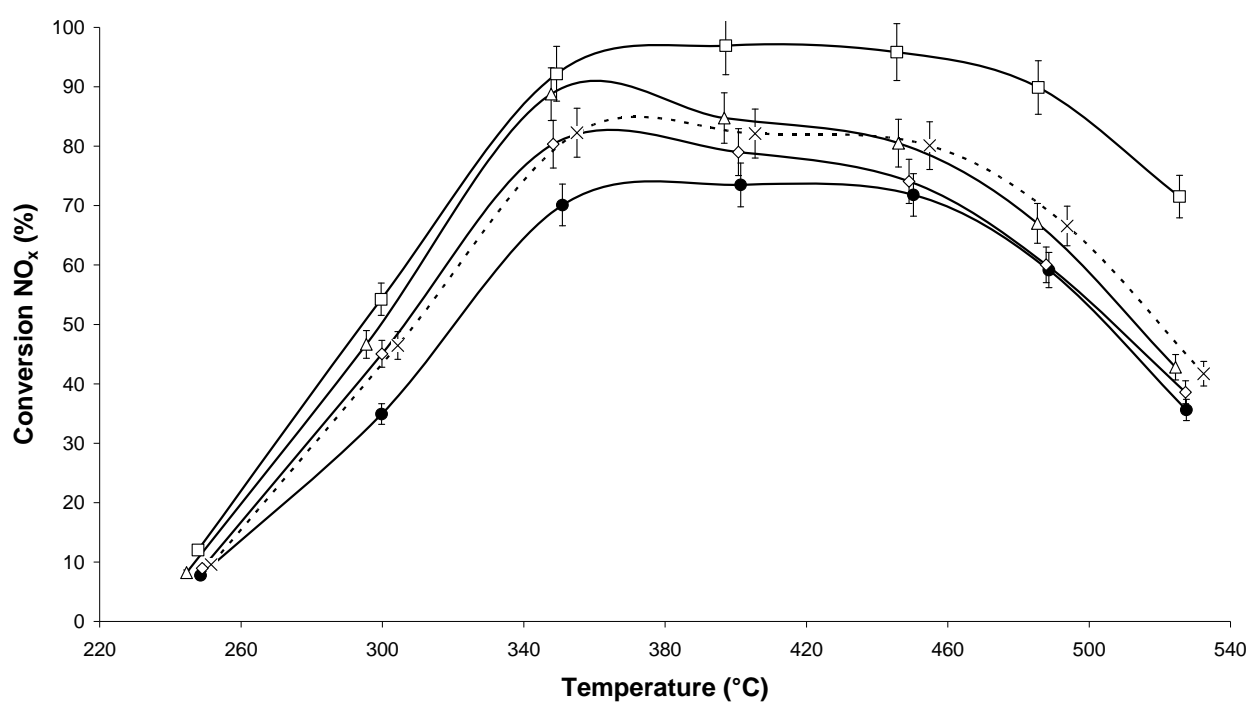

(a)

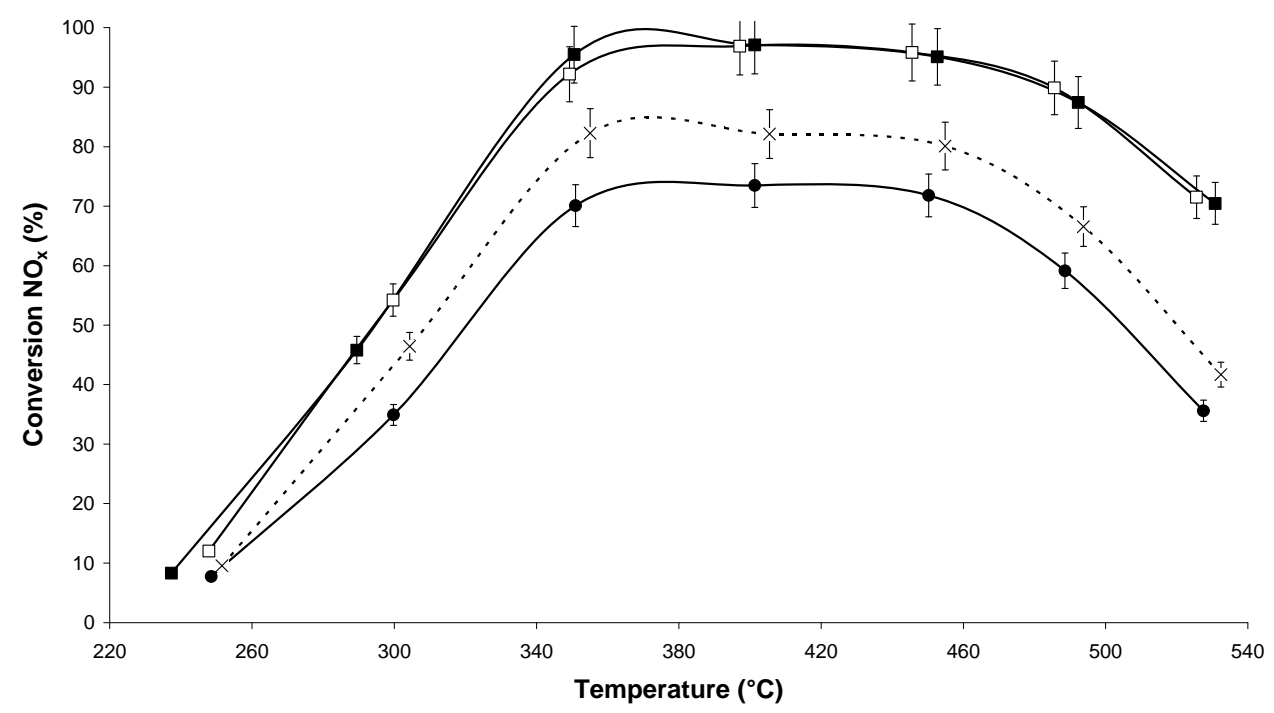

(b)

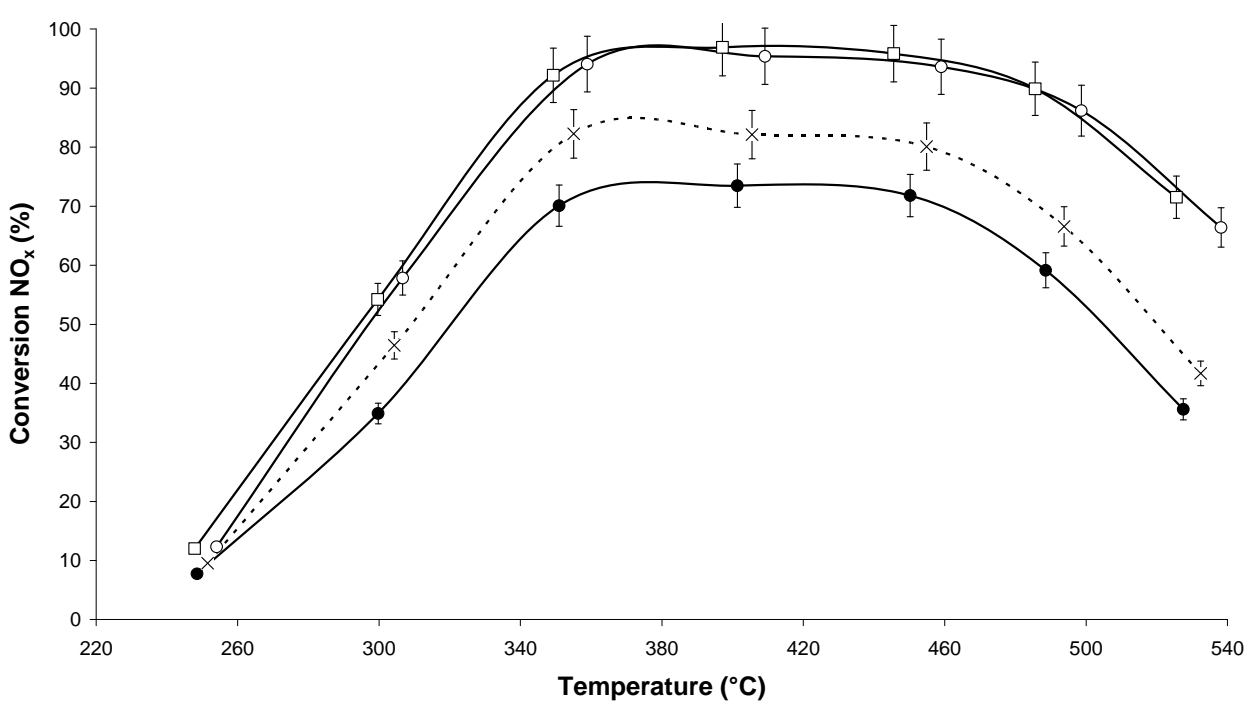

(c) 


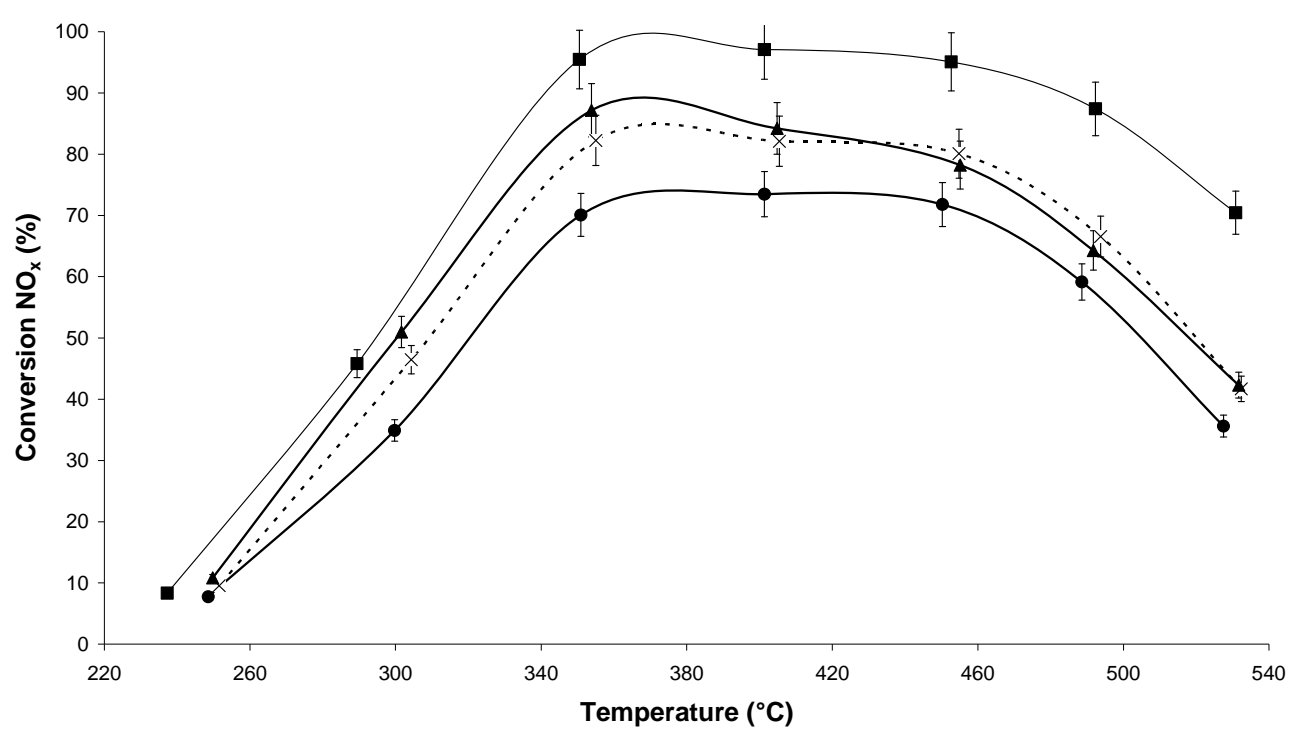

(d)

Figure 2. $\mathrm{NO}_{\mathrm{x}}$ conversion in $\mathrm{N}_{2}$ as function of temperature during the steady-state reaction of $\mathrm{NO}_{\mathrm{x}}$ reduction by EtOH over $\mathrm{Ag} / \mathrm{Al}_{2} \mathrm{O}_{3}$ catalyst; (a) As a function of different microwave plasma treatments at various time of treatment $(\diamond) \mathrm{M}$.W-1, ( $\square$ ) M.W-2, $(\triangle)$ M.W-3. And $(X)$ calcination, $(\bullet)$ without treatment; (b) As a function of different microwave plasma treatments at various powers: $(\square) \mathrm{M} . \mathrm{W}-2$, ( $\square)$ M.W-5. And (X) calcination, $(\bullet)$ without treatment; (c) As a function of different microwave plasma treatments at various carrier gas at $500 \mathrm{~W}:(\square) \mathrm{M} . \mathrm{W}-2,(O)$ M.W-4. And (X) calcination, (๑) without treatment; (d) As a function of different microwave plasma treatments at various carrier gas at $800 \mathrm{~W}:(\square)$ M.W-5, (A) M.W-6. And (X) calcination, $(\bullet)$ without treatment. (Reaction conditions: $500 \mathrm{ppm} \mathrm{NO}, 2500 \mathrm{ppm}$ EtOH, and 10 vol\% $\mathrm{O}_{2}$ in $\mathrm{Ar}$ at a flow rate of $184 \mathrm{~cm}^{3} \cdot \mathrm{min}^{-1}$ over $0.045 \mathrm{~g}$ alumina spheres catalyst $\left(\mathrm{GHSV}=\mathrm{Ag} / 190,000 \mathrm{~h}^{-1}\right)$ ).

\subsection{Characterization of the Plasma Treated Catalysts by Means of TPSR of NO $\mathrm{N}_{\mathrm{x}}$ in the Presence of Ethanol}

Temperature Programmed Surface Reactions (TPSR) were performed on the following samples: 1) untreated and 2) calcined samples and 3) all microwave plasma treated catalyst. Figure 3(a) shows the influence of the treatment time of microwave plasma. We can notice that the TPSR results are in agreement with the results obtained in steady-state conditions. The plasma-treated catalyst-named M.W-2 (500 W-Ar-30 min) allows a better adsorption of species $\mathrm{NO}_{\mathrm{x}}$, with $400^{\circ} \mathrm{C}$ this treatment reaches $88.8 \%$ $\mathrm{NO}_{\mathrm{x}}$ conversion. This conversion is very close to that obtained by the calcined sample with around $81 \% \mathrm{NO}_{\mathrm{x}}$ conversion at $365^{\circ} \mathrm{C}$. Whereas a M.W-1 plasma treatment (500 W-Ar-10 min) only leads to $57.2 \%$ of conversion and on M.W-3 (500 W-Ar-60 min) only $80.6 \%$ of conversion is obtained. We can see that its conversion decreases to reach at the end of the rise of temperature the M.W-1 plasma treatment.. If the treatment plasma M.W is prolonged then the catalyst will lose its effectiveness. On Figure 3(b), we compare the influence of the power of the plasma used. We notice that the all plasma treatments allow a good activation of catalyst since the $\mathrm{NO}_{\mathrm{x}}$ concentration are always lower for such catalysts compared to the sample without treatment. A NO desorption higher than $500 \mathrm{ppm}$ is observed for all the treatments in temperature. Whereas for the untreated sample, we distinguish that a $\mathrm{NO}_{\mathrm{x}}$ desorption around $250^{\circ} \mathrm{C}$ indicating that the sites of adsorption are not all free sites. Figure 3(c) shows the influence of the nature of the carrier gas. The obtained results are comparable with those obtained in steady-state conditions (Figure 2). The M.W-4 plasma treatment (500 W-20\% oxygen/argon-30 min) leads to lower conversion of $\mathrm{NO}_{\mathrm{x}}$ than the M.W-2 plasma treatment under Argon. This effect of the carrier gas $20 \% \mathrm{O}_{2} /$ $\mathrm{Ar}$ is also reproduced with microwave plasma with $800 \mathrm{~W}$. On Figure 3(d), one can see that a sample treated with a plasma under argon (M.W-5) converts more $\mathrm{NO}_{\mathrm{x}}$ at high temperature than a sample treated with a microwave plasma under $20 \%$ oxygen/argon (M.W-6).

\subsection{Influence of Microwave Plasma Treatment on TGA-DTA}

The effect of the plasma activation was followed by means of DTG-DTA, analyses were performed on: 1) untreated freshcatalyst; and 2) microwave treated catalysts; and 3) calcined catalysts.

From Figures 4(a) and (b), presenting the thermogravimetric and differential thermal analysis results, the initial weight loss with a maximum close to $100^{\circ} \mathrm{C}$ corresponds to the loss of physisorbed water [23]. The TGA curve indicates a major weight loss up to $200^{\circ} \mathrm{C}$. Hence, 


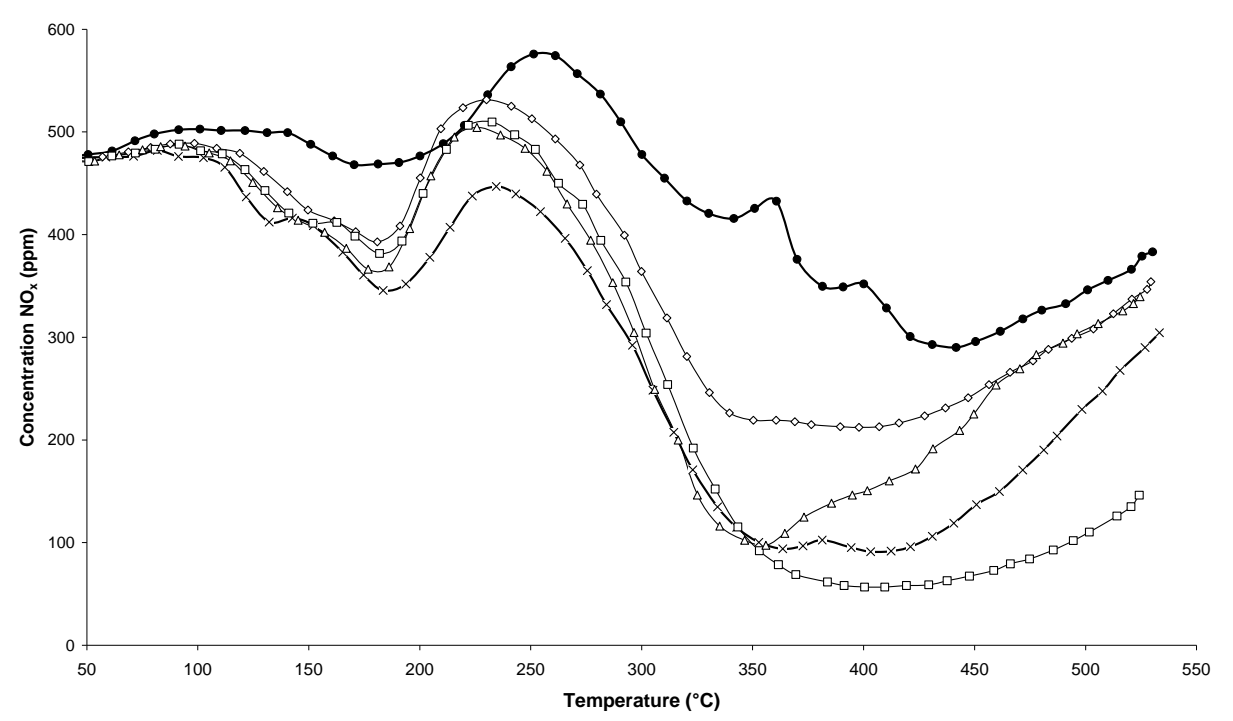

(a)

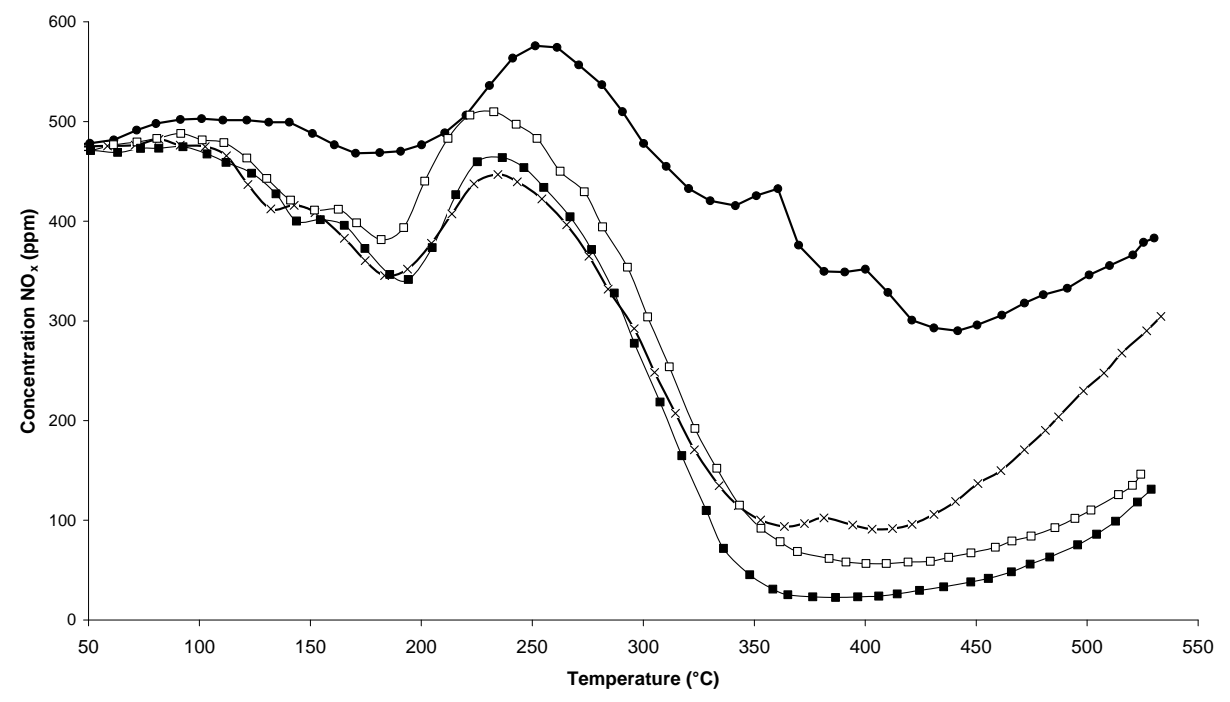

(b)

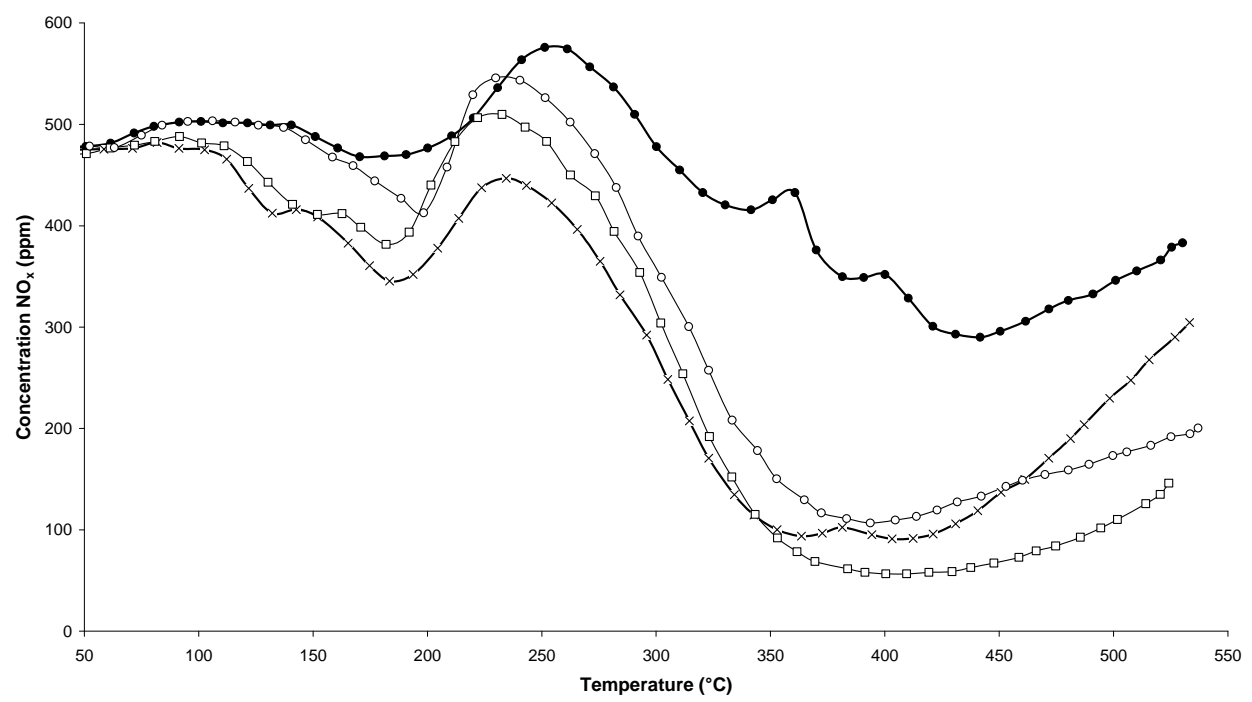

(c) 


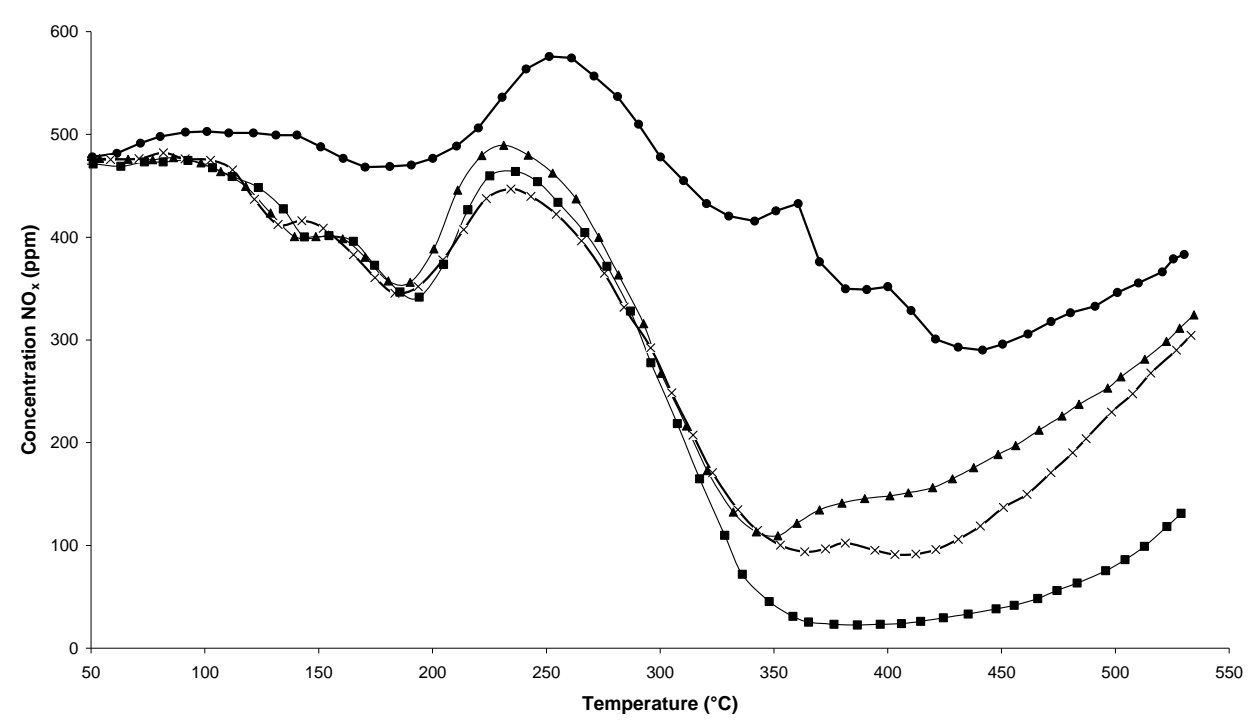

(d)

Figure 3. Temperature programmed surface reaction as function of temperature during the reaction of $\mathrm{NO}_{\mathrm{x}}$ reduction by EtOH over $\mathrm{Ag} / \mathrm{Al}_{2} \mathrm{O}_{3}$ catalyst. (a) As a function of different microwave plasma treatments at various time of treatment $(\diamond)$ M.W-1, ( $\square)$ M.W-2, $(\triangle)$ M.W-3. And $(X)$ calcination, (๑) without treatment; (b) As a function of different microwave plasma treatments at various powers: $(\square)$ M.W-2, $(\square)$ M.W-5. And $(X)$ calcination, $(\bullet)$ without treatment; (c) As a function

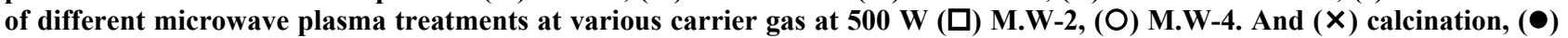
without treatment; (d) As a function of different microwave plasma treatments at various carrier gas at 800 W: ( $\square)$ M.W-5, (A) M.W-6. And $(X)$ calcination, $(\bullet)$ without treatment. (Reaction conditions: 500 ppm NO, 2500 ppm EtOH, and 10 vol\% $\mathrm{O}_{2}$ in Ar at a flow rate of $184 \mathrm{~cm}^{3} \cdot \mathrm{min}^{-1}$ over $0.045 \mathrm{~g} \mathrm{Ag} / \mathrm{g}$-alumina spheres catalyst $\left(\mathrm{GHSV}=190,000 \mathrm{~h}^{-1}\right)$ ).

this loss can be attributed to $\mathrm{NO}_{3}$ ligands. In Figure 4(b), the TGA plot shows exothermic peaks in the temperature range $200^{\circ} \mathrm{C}-550^{\circ} \mathrm{C}$. Furthermore, the loss of $\mathrm{NO}_{3}$ ligands from the surface corresponds to the weight loss observed between $200^{\circ} \mathrm{C}$ and $550^{\circ} \mathrm{C}$.

TGA results indicate that the calcination at $500^{\circ} \mathrm{C}$ has totally eliminated these nitrates.

The TGA of the calcined samples at various temperatures were presented in Figure 5.

This study will able us to follow the nitrates elimination on the silver based catalysts. First of all, no effect is observed on the decomposition of nitrates when a calcination at $100^{\circ} \mathrm{C}$ is performed. Then, with a treatment in air at $200^{\circ} \mathrm{C}$, we notice a first change. Thus a $200^{\circ} \mathrm{C}$ treatment leads to a decrease of the ligand-support interaction. Finally, the $400^{\circ} \mathrm{C}$ treatment reduces the range of temperature clearly related to the nitrate species which goes from $\left[200^{\circ} \mathrm{C}-550^{\circ} \mathrm{C}\right]$ to $\left[350^{\circ} \mathrm{C}-550^{\circ} \mathrm{C}\right]$.

Finally, we analyzed the various samples treated by plasma M.W-1, M.W-2 and M.W-3. In the Figure 6(a), we can follow the effect of the processing time plasma on the decomposition of nitrates of $\left[200^{\circ} \mathrm{C}\right.$ with $\left.550^{\circ} \mathrm{C}\right]$. We can notice that the more the processing time increases, the less there are nitrate species, which will desorb. The processing time microwave plasma has a positive influence on the decomposition of nitrates.

The effect of power used in plasma reactor was also studied (Figure 6(b)). We can notice that when the po- wer increases to 800 Watt, it remains a low concentration of nitrate on the surface of catalyst. Thus, we can conclude that an increase of the microwave plasma power leads to a positive influence on the decomposition of nitrates.

On Figures 6(c) and (d), we follow the influence of oxygen in the mixture of the carrier gas on the decomposition of nitrates, for M.W. plasma with 500 Watt and 800 Watt respectively. We can notice that when the power is higher than $500 \mathrm{~W}$ the presence of oxygen in the plasma treatment shifted the temperature range of decomposition of nitrates. The M.W-4 plasma treatment leads to weak the nitrate-support bonds. Nevertheless, using the M.W-6 treatment under 800 Watt under $20 \%$ $\mathrm{O}_{2} / \mathrm{Ar}$, it remains some nitrate species on the surface of catalyst. As conclusion, we can note that the effect of the microwave plasma power is more important than the nature of the gas in plasma itself on the decomposition of nitrates. These characterizations confirm the results obtained in catalytic activity (Figures 2 and 3). We can also conclude that the M.W. plasma treatments in FBR are not as efficient as a typical calcination for overall nitrate species removal. However, a plasma treatment for 30 min in Ar led to a higher $\mathrm{NO}_{\mathrm{x}}$ removal in $\mathrm{SCR}$ of $\mathrm{NO}_{\mathrm{x}}$ by ethanol reaction.

Thus, we can suppose that these nitrates species that are left on the surface during the plasma treatment process can play an important role in $\mathrm{SCR}$ of $\mathrm{NO}_{\mathrm{x}}$ by ethanol 


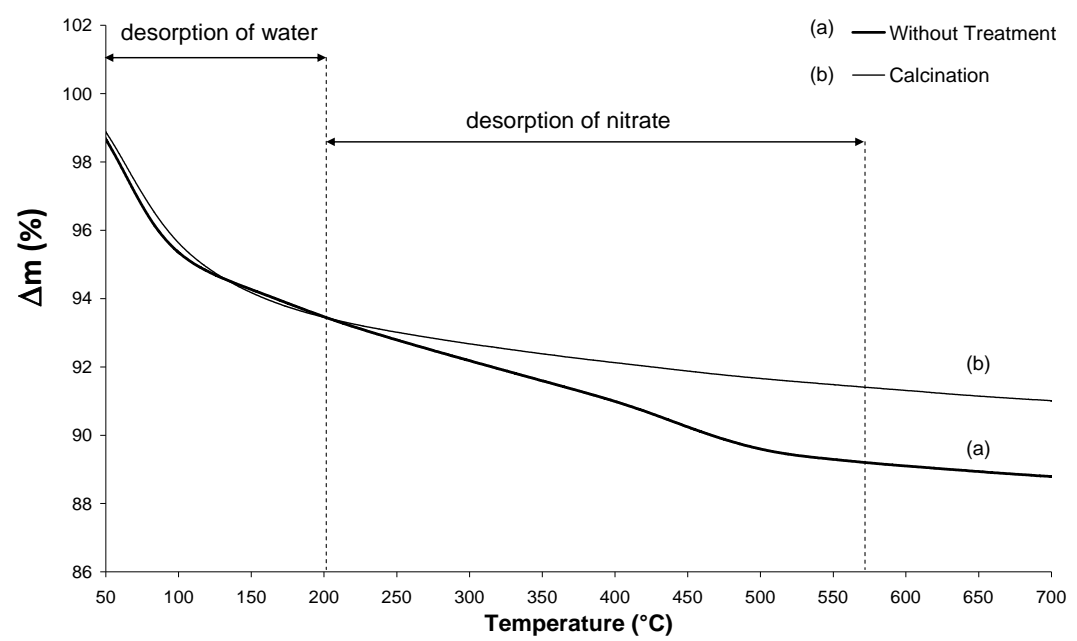

(i)

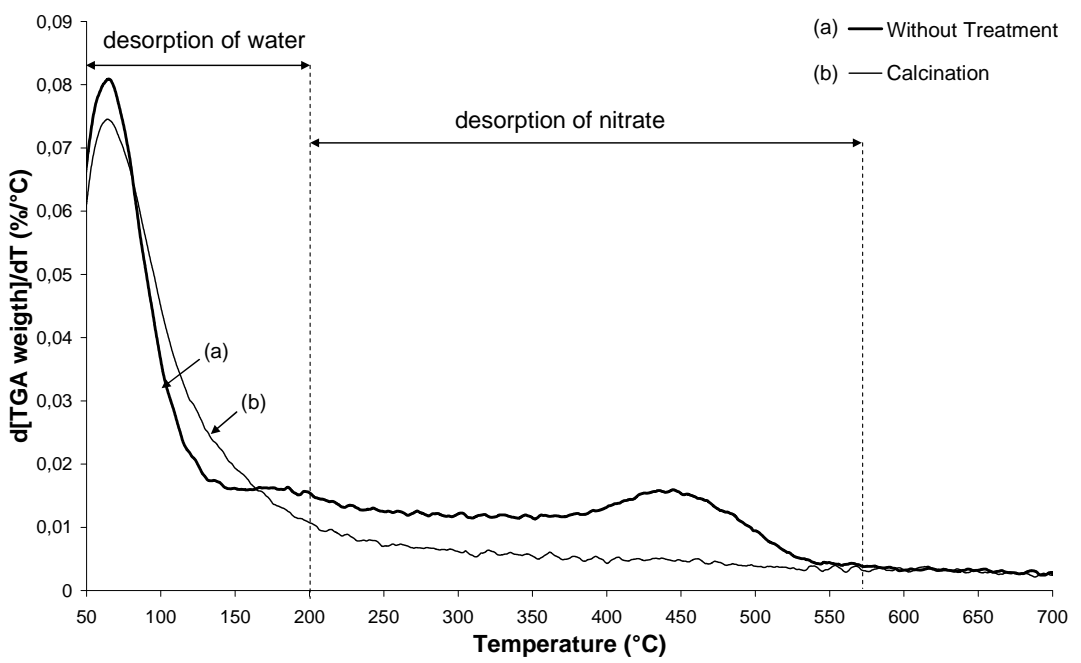

(ii)

Figure 4. TGA analysis. (i) of $2.5 \%$ silver ong- $\mathrm{Al}_{2} \mathrm{O}_{3}$ spheres: (a) untreated sample, (b) calcinations; (ii) of $2.5 \%$ silver ong- $\mathrm{Al}_{2} \mathrm{O}_{3}$ spheres: (a) untreated sample, (b) calcination.

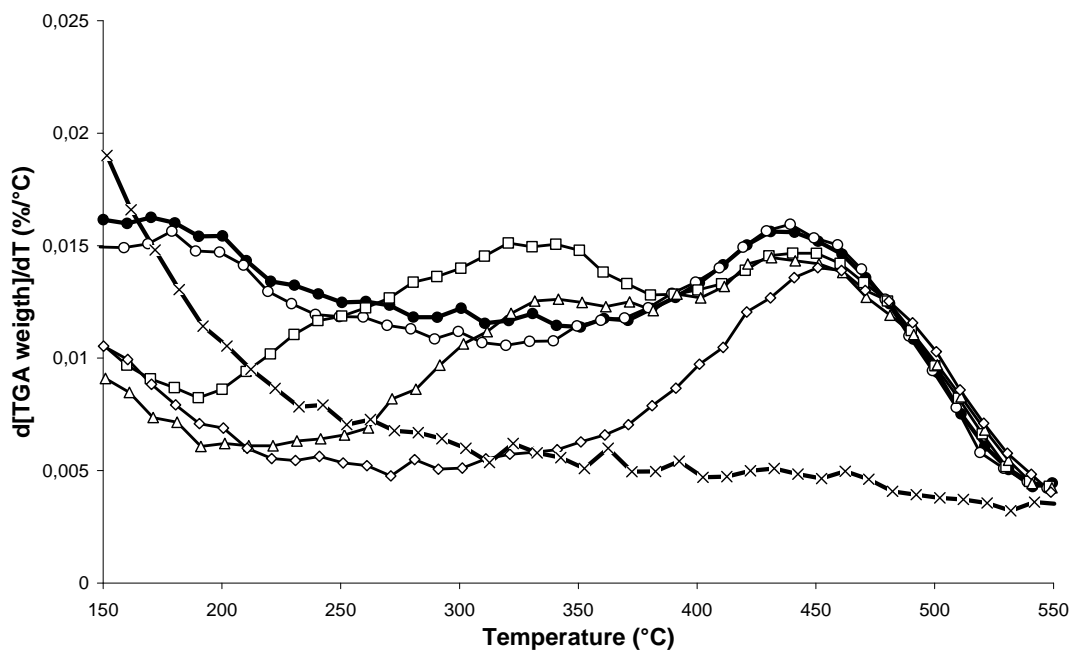

Figure 5. DTG analysis of $2.5 \%$ silver ong- $\mathrm{Al}_{2} \mathrm{O}_{3}$ spheres after various temperature of calcination: $(\times) 500^{\circ} \mathrm{C}-2 \mathrm{~h},(\diamond)$ $400^{\circ} \mathrm{C}-2 \mathrm{~h},(\triangle) 300^{\circ} \mathrm{C}-2 \mathrm{~h},(\square) 200^{\circ} \mathrm{C}-2 \mathrm{~h},(O) 100^{\circ} \mathrm{C}-2 \mathrm{~h},(\bullet)$ without treatment. Heating rate: $10^{\circ} \mathrm{C} / \mathrm{min}$, carrier gas: air, final temperature: $800^{\circ} \mathrm{C}$. 


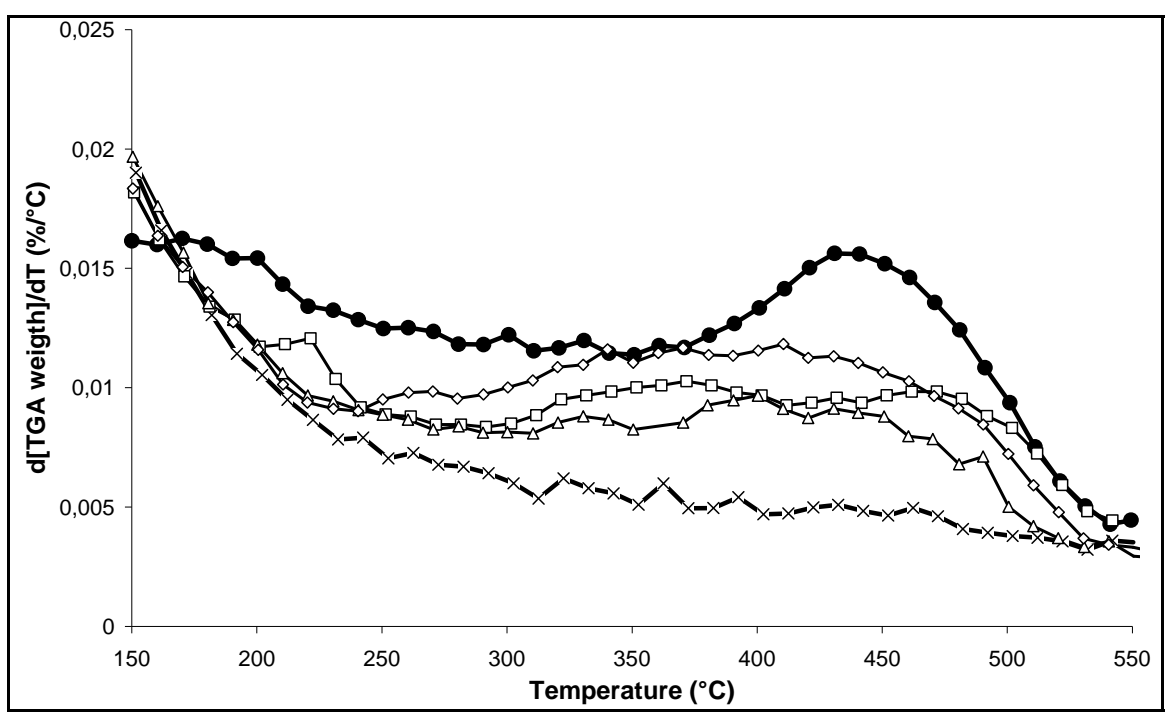

(a)

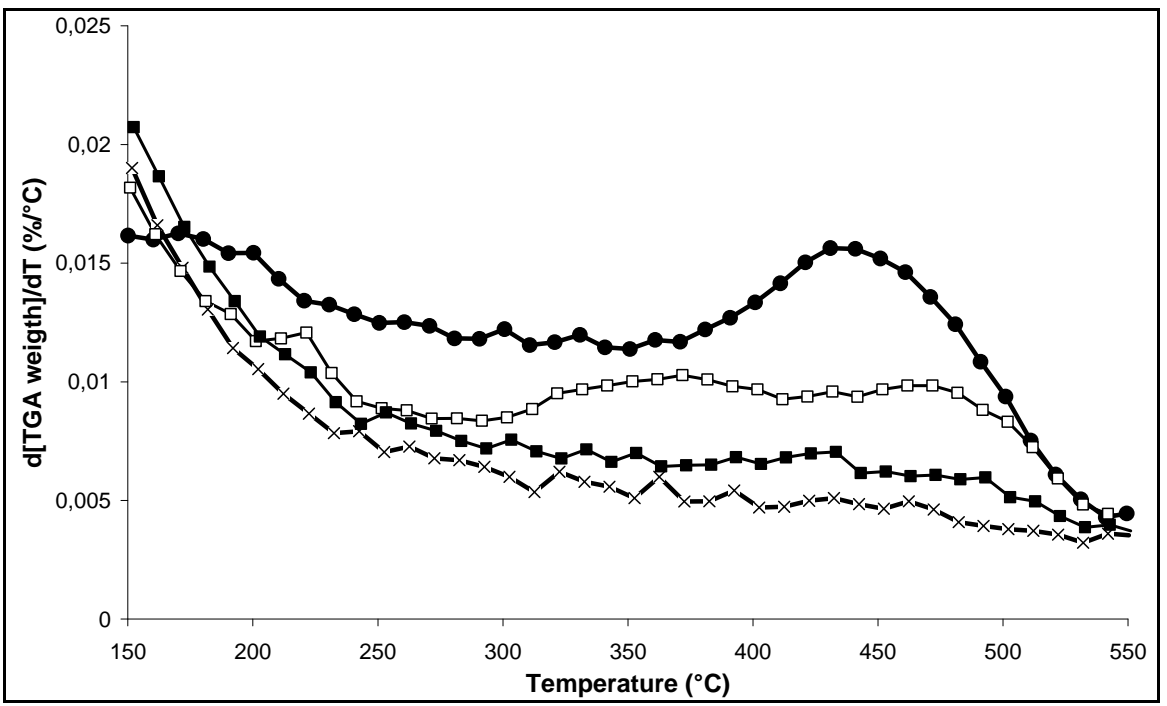

(b)

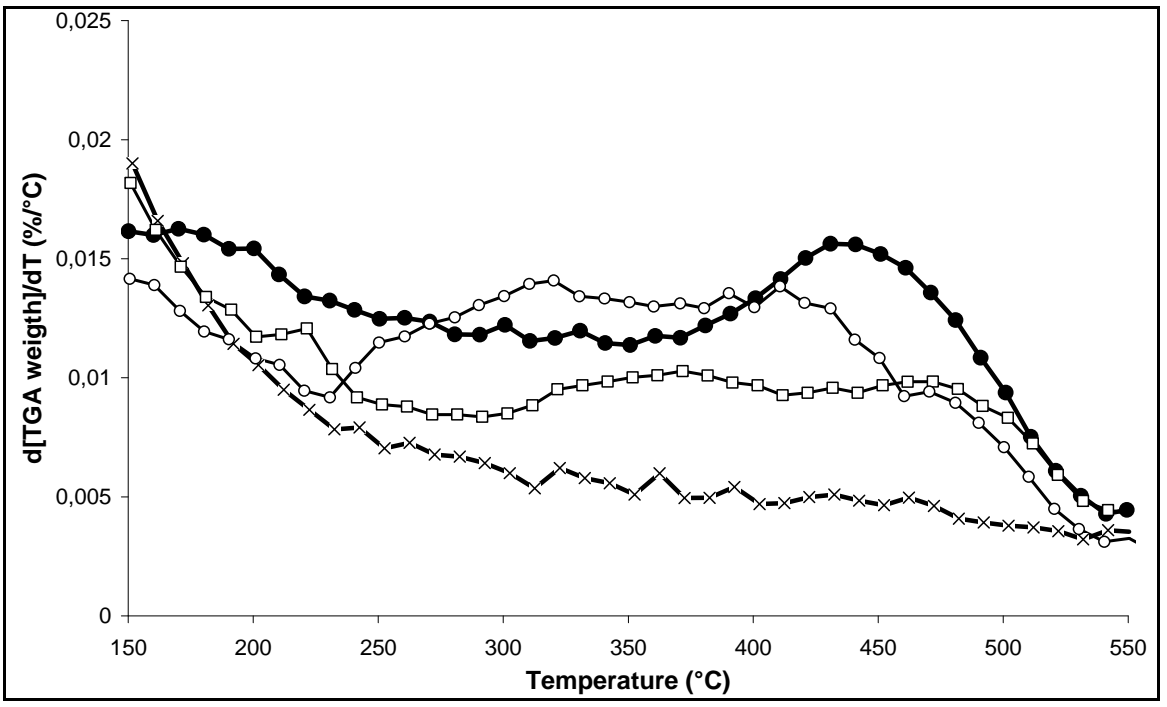

(c) 


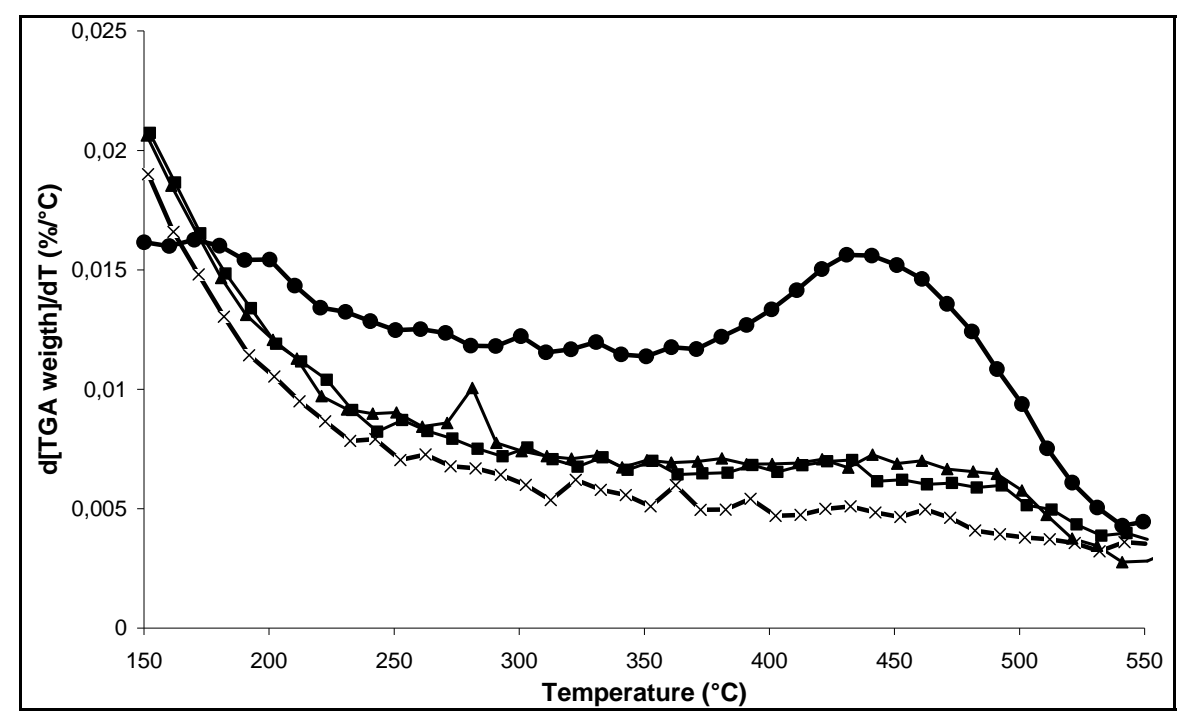

(d)

Figure 6. TGD analysis of $2.5 \%$ silver ong- $\mathrm{Al}_{2} \mathrm{O}_{3}$ spheres; (a) As a function of different microwave plasma treatments at various times of treatment $(\diamond)$ M.W-1, $(\square)$ M.W-2, $(\triangle)$ M.W-3. And $(X)$ calcination, $(\bullet)$ without treatment; (b) As a function of

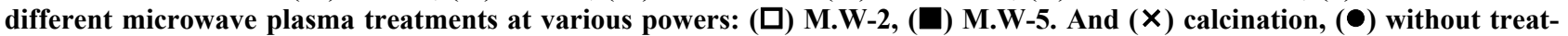
ment; (c) As a function of different microwave plasma treatments at various carrier gas at 500 W: ( $\square$ ) M.W-2, (O) M.W-4. And $(X)$ calcination, $(\bullet)$ without treatment; (d) As a function of different microwave plasma treatments at various carrier gas at $800 \mathrm{~W}$ : (ם) M.W-5, (A) M.W-6. And $(X)$ calcination, $(\bullet)$ without treatment. (Heating rate: $10^{\circ} \mathrm{C} / \mathrm{min}$, carrier gas: air, final temperature: $\left.800^{\circ} \mathrm{C}\right)$.

reaction. Further in-situ investigations will be performed on those samples in order to draw a SCR mechanism.

\subsection{Identification of Active Silver Species}

It is known that during the calcination process, $\mathrm{AgO}$ or $\mathrm{AgO}_{2}$ phases are then obtained from the decomposition of silver nitrate as it was described by Musi et al. [17]. The specific surface area (BET) is about $170 \mathrm{~m}^{2} \cdot \mathrm{g}^{-1}$ for all studied samples. Nosilver particles $\left(\mathrm{AgO}, \mathrm{Ag}^{0}\right)$ are detected by TEM coupled by EDS even EDS measurements show that silver is well dispersed on the support as $\mathrm{Ag} / \mathrm{Al}$ ratio is always constant (Figure not shown).

In the UV-Vis spectroscopy was used in order to investigate the silver species on the different used catalysts. On calcined samples (Figure 7(a)), peaks at 212, 260, 290, 330, and $437 \mathrm{~nm}$ are observed. The peaks at 212 and $260 \mathrm{~nm}$ are generally attributed to the $4 \mathrm{~d}^{10}$ to $4 \mathrm{~d}^{9} \mathrm{~s}$ transition of highly dispersed $\mathrm{Ag}^{+}$cations [24-26]. From the literature, the peak found at ca. $290 \mathrm{~nm}$ is linked to $\mathrm{Ag}_{\mathrm{n}}^{\mathrm{m}+}$ clusters [25]. However, Martinez-Arias et al. proposed that this peak could be due to electronic transitions of reduced Ag species [27]. This peak could also correspond to the shifted peak of silver aluminate, usually observed at $230 \mathrm{~nm}$ [25]. The peak at $330 \mathrm{~nm}$ is generally assigned to $\mathrm{Ag}_{\mathrm{n}}^{\mathrm{m}+}$ clusters [24-27]. The last one at $437 \mathrm{~nm}$ corresponds to metallic silver particles [24-27]. There are more oxidized silver species with the plasma treatment. Furthermore, there is the same band for the cluster species between the plasma treatment and calcination.

Moreover, there are even more metallic species with the plasma treatment. Thus, metallic silver $\mathrm{Ag}^{0}$ promotes the reaction of $\mathrm{NO}_{\mathrm{x}}$ reduction at the low temperatures and the reaction of oxidation of the reducing agent [17, 25,28,29]. Figure 7(a) indicates that the samples M.W-1, M.W-2 and M.W-3 present the same species than those present on untreated samples. Figure 7(c) shows that the plasma treatment M.W-4 leads to the presence of $\mathrm{Ag}_{\mathrm{n}}^{\mathrm{m}+}$ clusters (at $290 \mathrm{~nm}$ ). These cationic cluster species are present in lower concentration on M.W-4 plasma treated samples. This observation can explain the low catalytic activity of these latter samples. In Figures 7(b) and (d), we can conclude that the species present on M.W-5 (800 Watt) samples are similar than those present on the calcined sample.

\section{Conclusions}

Microwave Fluidized bed plasma reactor treated alumina silver based catalysts lead to higher $\mathrm{NO}_{\mathrm{x}}$ reduction efficiency in ethanol SCR than calcined catalyst. Despite a lower nitrate desorption, as observed by DTGstudies, it has been clearly shown that microwave plasma process leads to the formation of different and more reactive silver species. Further in-situ investigations are in course in order to explain these differences. In this study, we used a microwave source generator. Thus microwave plasmas 


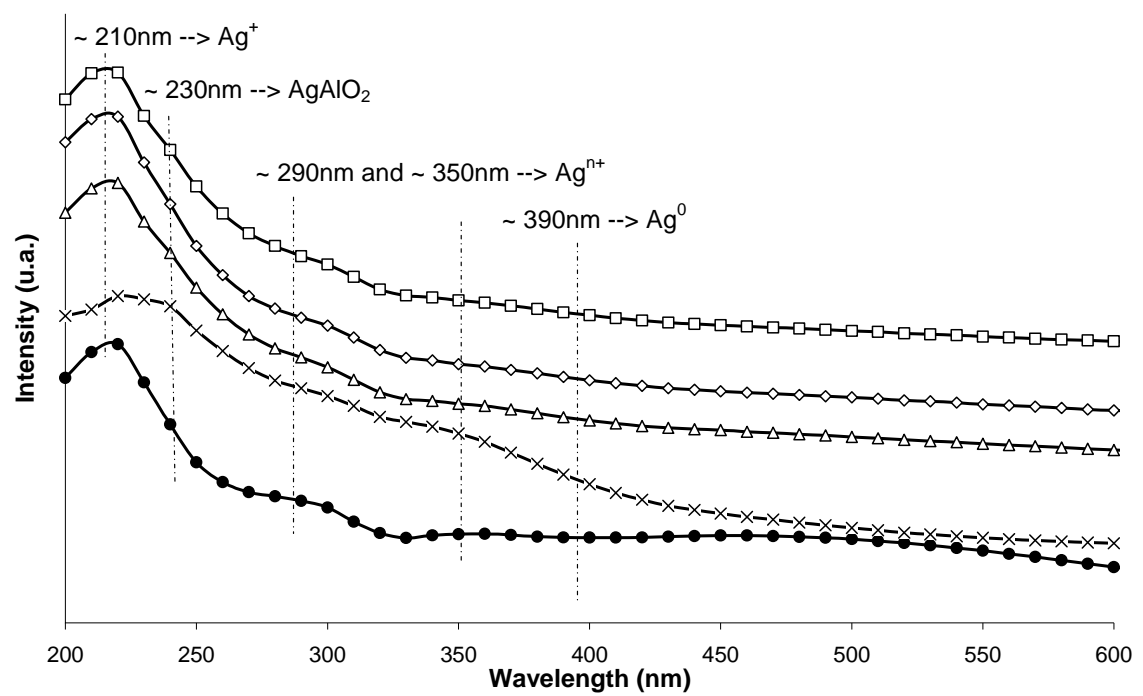

(a)

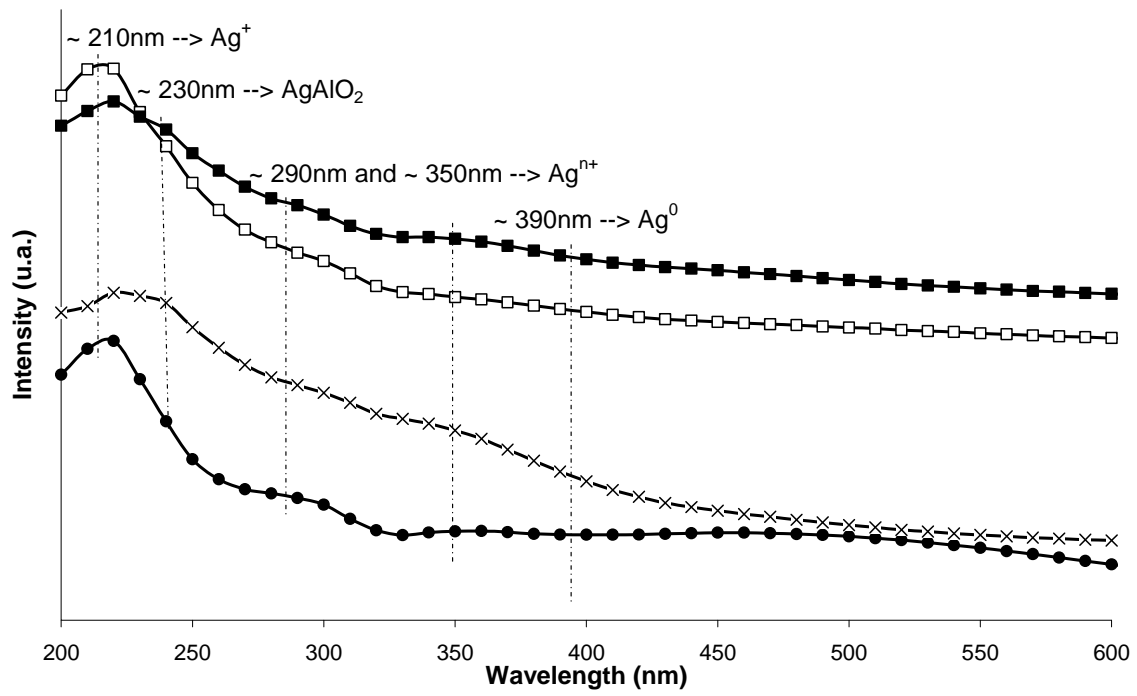

(b)

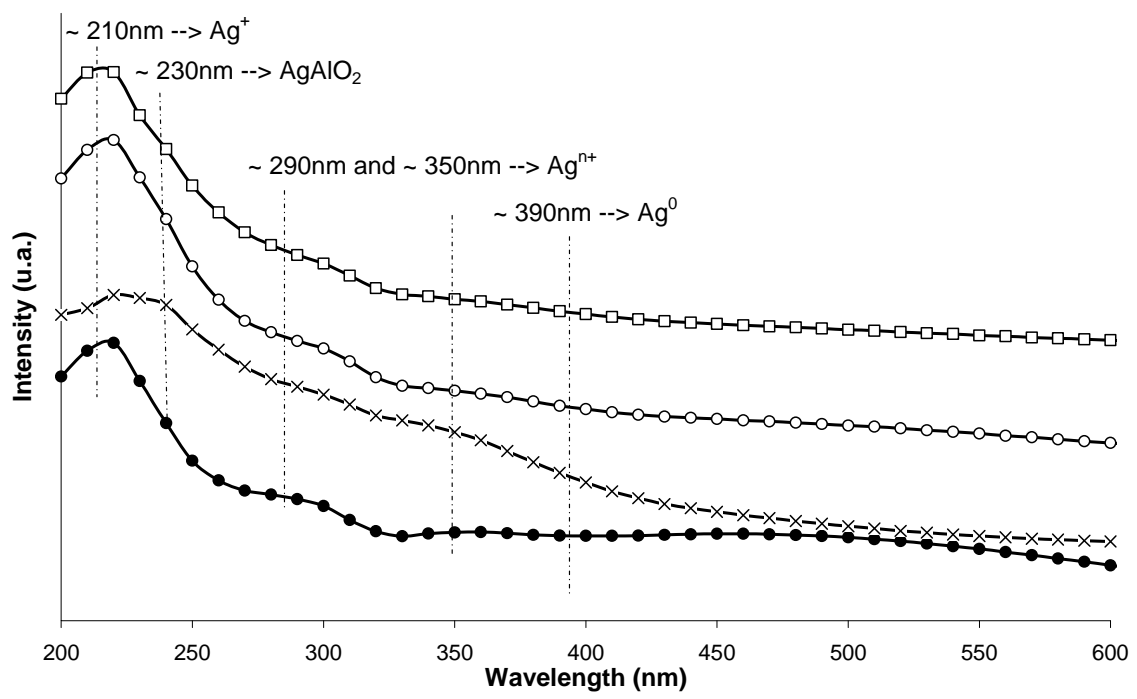

(c) 


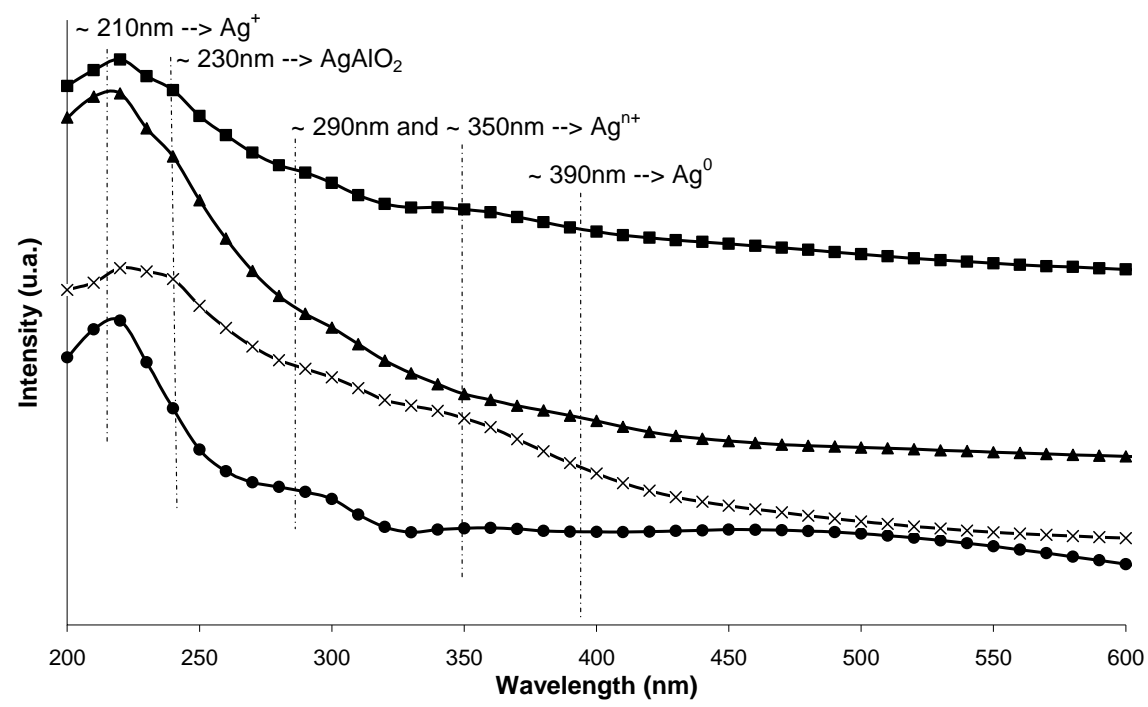

(d)

Figure 7. UV-visible-NIR diffuse reflectance spectra of $\mathrm{Ag} / \mathrm{g}-\mathrm{Al}_{2} \mathrm{O}_{3}$, (a) As a function of different microwave plasma treatments at various times of treatment: $(\diamond)$ M.W-1, $(\square)$ M.W-2, $(\triangle)$ M.W-3. And $(X)$ calcination, $(\bullet)$ without treatment; (b) As

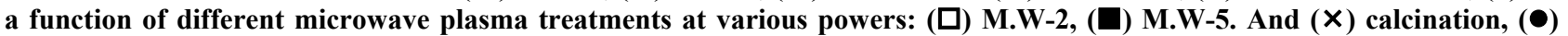
without treatment; (c) As a function of different microwave plasma treatments at various carrier gas at 500 W ( $\square$ ) M.W-2, $(O)$ M.W-4. And $(X)$ calcination, $(\bullet)$ without treatment; (d) As a function of different microwave plasma treatments at vari-

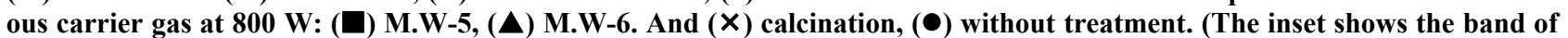
metallic and oxidized Ag).

present the advantage to possess higher density of energy in comparison to radio frequency plasmas. Furthermore, positive effects could be expected regarding the elimination of ligands and the use lower plasma treatment times. All the plasma treated samples lead to higher conversion of $\mathrm{NO}_{\mathrm{x}}$ than a sample without treatment. The influence of the parameters such as the process time, the power and the nature of the carrier gas have an effect on the decomposition of nitrates and thus on the reduction of $\mathrm{NO}_{\mathrm{x}}$. The increase of the microwave plasma power has a positive influence on the decomposition of nitrates. The plasma treatment with 500 Watt can be associated with a calcination of $400^{\circ} \mathrm{C}$. We can thus conclude that a classical calcination can be easily replaced by a plasma treatment such as microwave plasma treatment on alumina silver based catalysts, which are potential catalysts for $\mathrm{SCR} \mathrm{NO}_{\mathrm{x}}$ by Ethanol. For 800 Watt treatment, we can conclude that it presents the same effect than calcination at $500^{\circ} \mathrm{C}$. In order to draw a mechanism for SCR of $\mathrm{NO}_{\mathrm{x}}$ on activated microwave plasma alumina supported silver catalysts, further in-situ investigations will be performed. The aim will be to determine the role of the nitrates species that are left on the surface during the plasma treatment process versus a classical calcination process.

Moreover, other supports will be studied to show the benefits of plasma activation process in FBR. Thus, zeolites and mesoporous materials (SBA-15) are actually in use. The first results confirm those observed on aluminasupported catalysts. Finally, Optical Emission Spectros- copy (OES) is in course to have a better understanding of the plasma itself and its interaction with the surface of catalysts $[30,31]$.

\section{REFERENCES}

[1] C.-J. Liu, G. P. Vissokov and W. L. Jang Ben, "On the Plasma-Chemical Synthesis and/or Regeneration of Ultradispersed Catalysts for Ammonia Production," Catalysis Today, Vol. 72, No. 3-4, 2002, pp. 173-184. doi:10.1016/S0920-5861(01)00493-X

[2] F. Pinna, "Supported Metal Catalysts Preparation," Catalysis Today, Vol. 41, No. 1, 1998, pp. 129-137. doi:10.1016/S0920-5861(98)00043-1

[3] M. Campanati, G. Fornasari and A. Vaccari, "Fundamentals in the Preparation of Heterogeneous Catalysts," Catalysis Today, Vol. 77, No. 4, 2003, pp. 299-314. doi:10.1016/S0920-5861(02)00375-9

[4] K. Kiyokawa, H. Matsuoka, A. Itou, K. Hasegawa and K. Sugiyama, "Decomposition of Inorganic Gases in an Atmospheric Pressure Non-Equilibrium Plasma," Surface and Coating Technology, Vol. 112, No. 1, 1999, pp. 25-28. doi:10.1016/S0257-8972(98)00762-2

[5] X. T. Deng, J. J. Shi and M. G. Kong, "Protein Destruction by a Heliumatmospheric Pressure Glow-Discharge: Capability and Mechanisms," Journal of Applied Physics, Vol. 101, No. 7, 2007, pp. 074701-074703. doi:10.1063/1.2717576

[6] J. F. Kolb, et al., "Cold Atmospheric Pressure Air Plasma jet for Medical Applications," Applied Physics Letters, Vol. 92, No. 24, 2008, pp. 241501-241503. 
doi:10.1063/1.2940325

[7] G. P. Vissokov, K. D. Manolovaet and L. B. Brakalov, "Chemical Preparation of Ultra-Fine Aluminium Oxide by Electric Arc Plasma," Journal of Materials Science, Vol. 16, No. 6, 1981, pp. 1716-1719. doi:10.1007/BF02396898

[8] W. Xia, O. F.-K. Schlüter, C. Liang, M. W. E. Van den Berg, M. Guraya and M. Muhler, "The Synthesis of Structured $\mathrm{Pd} / \mathrm{C}$ Hydrogenation Catalysts by the Chemical Vapor Deposition of Pd(allyl)Cp onto Functionalized Carbon Nanotubes Anchored to Vapor Grown Carbon Microfibers," Catalysis Today, Vol. 102-103, 2005, pp. 34-39. doi:10.1016/j.cattod.2005.02.002

[9] L. Rouleau, R. Bacaud and M. Breysse, "A PlasmaProduced Dispersed and Disposable Supported Nickel Catalyst for Hydroconversion of Heavy Oils: I. Preparation and Characterization," Applied Catalysis A: General, Vol. 104, No. 2, 1993, pp. 137-147. doi:10.1016/0926-860X(93)85094-6

[10] M. Karches, C. Bayer and P. Rudolf von Rohr, "A Circulating Fluidised Bed for Plasma-Enhanced Chemical Vapor Deposition on Powder Sat Low Temperatures," Surface and Coatings Technology, Vol. 116-119, 1999, pp. 879-885. doi:10.1016/S0257-8972(99)00194-2

[11] M. Foix, C. Guyon, M. Tatoulian and P. Da Costa, "Study of the Use of Fluidized Bed Plasma Reactors for the Treatment of Alumina Supported Palladium Catalyst: Application for SCR $\mathrm{NO}_{x}$ by $\mathrm{CH}_{4}$ in Stationary Sources," Catalysis Communications, Vol. 12, No. 1, 2010, pp. 2024. doi:10.1016/j.catcom.2010.05.022

[12] R. Jafari, M. Tatoulian, W. Morscheidt and F. ArefiKhonsari, "Stable Plasma Polymerized Acrylic Acid Coating Deposited on Polyethylene (PE) Films in a Low Frequency Discharge (70 kHz)," Reactive and Functional Polymers, Vol. 66, No. 12, 2006, pp. 1757-1765. doi:10.1016/j.reactfunctpolym.2006.08.006

[13] C. J. Liu, K. Yu, Y. P. Zhang, X. Zhu, F. He and B. Eliasson, "Characterization of Plasma Treated Pd/HZSM-5 Catalyst for Methane Combustion," Applied Catalysis, Vol. 47, No. 2, 2004, pp. 95-100. doi:10.1016/i.apcatb.2003.07.005

[14] Y. Zhao, Y. X. Pan, L. Cui and C. J. Liu, "Carbon Nanotube Formation over Plasma Reduced Pd/HZSM-5," Diamond and Related Materials, Vol. 16, No. 2, 2007, pp. 229-235. doi:10.1016/j.diamond.2006.05.012

[15] R. Bartolomeu, M. Foix, A. Fernandes, M. Tatoulian, M. F. Ribeiro, C. Henriques and P. Da Costa, "Fluidized Bed Plasma for Pre-Treatment of Co-Ferrierite Catalysts: An Approach to $\mathrm{NO}_{x}$ Abatement," Catalysis Today, Vol. 176, No. 1, 2011, pp. 234-238. doi:10.1016/j.cattod.2010.12.051

[16] J. P. Breen, R. Burch and H. M. Coleman, "Metal-Catalysed Steam Reforming of Ethanol in the Production of Hydrogen for Fuel Cell Applications," Applied Catalysis B: Environmental, Vol. 39, No. 1, 2002, pp. 65-74. doi:10.1016/S0926-3373(02)00075-9

[17] A. Musi, P. Massiani, D. Brouri, J. M. Trichard and P. Da Costa, "On the Characterisation of Silver Species for SCR of $\mathrm{NO}_{x}$ with Ethanol," Catalysis Letters, Vol. 128, No.
1-2, 2009, pp. 25-30. doi:10.1007/s10562-008-9694-Z

[18] F. Bretagnol, M. Tatoulian, F. Arefi-Khonsari, G. Lorang and J. Amouroux, "Surface Modification of Polyethylene Powder by Nitrogen and Ammonia Low Pressure Plasma in a Fluidized Bed Reactor," Reactive and Functional Polymers, Vol. 61, No. 2, 2004, pp. 221-232. doi:10.1016/j.reactfunctpolym.2004.06.003

[19] M. Tatoulian, F. Bretagnol, F. Arefi-Konsari, J. Amouroux, O. Bouloussa, F. Rondelez, A. John Paul and R. Mitchell, "Plasma Deposition of Allylamine on Polymer Powders in a Fluidized Bed Reactor," Plasma Processes and Polymers, Vol. 2, No. 1, 2005, pp. 38-44. doi:10.1002/ppap.200400029

[20] E. Sayah, D. Brouri, Y. H. Wu, A. Musi, P. Da Costa and P. Massiani, "A TEM and UV-Visible Study of Silver Reduction by Ethanol in Ag-Alumina Catalysts," Applied Catalysis A: General, Vol. 406, No. 1, 2011, pp. 94-101. doi:10.1016/j.apcata.2011.08.016

[21] B. M. Weckhuysen, A. A. Verberckmoes, J. Debaere, K. Ooms, I. Langhans and R. A. Schoonheydt, "In Situ UVVis Diffuse Reflectance Spectroscopy-On Line Activity Measurements of Supported Chromium Oxide Catalysts: Relating Isobutane Dehydrogenation Activity with $\mathrm{Cr}$ Speciation via Experimental Design," Journal of $\mathrm{Mo}$ lecular Catalysis A: Chemical, Vol. 151, No. 1-2, 2000, pp. 115-131. doi:10.1016/S1381-1169(99)00259-9

[22] P. J. M. Dijkgraaf, H. A. M. Duisters, B. F. M. Kuster and K. Van der Wiele, "Deactivation of Platinum Catalysts by Oxygen: 2. Nature of the Catalyst Deactivation," Journal of Catalysis, Vol. 112, No. 2, 1988, pp. 337-344. doi:10.1016/0021-9517(88)90147-9

[23] J. C. Martína, S. Suarezb, M. Yatesa and P. Ávila, "Pd/ $\gamma$ $\mathrm{Al}_{2} \mathrm{O}_{3}$ Monolithic Catalysts for $\mathrm{NO}_{\mathrm{x}}$ Reduction with $\mathrm{CH}_{4}$ in Excess of $\mathrm{O}_{2}$ : Effect of Precursor Salt," Chemical Engineering Journal, Vol. 150, No. 1, 2009, pp. 8-14. doi:10.1016/j.cej.2008.11.050

[24] A. Keshavaraja, X. She and M. Flytzani-Stephanopoulos, "Selective Catalytic Reduction of NO with Methane over Ag-Alumina Catalysts," Applied Catalysis B, Vol. 27, No. 1, 2000, pp. L1-L9. doi:10.1016/S0926-3373(00)00131-4

[25] N. Bogdanchikova, F. C. Meunier, M. Avaloj-Borja, J. P. Breen and A. Pestrykov, "On the Nature of the Silver Phases of $\mathrm{Ag} / \mathrm{Al}_{2} \mathrm{O}_{3}$ Catalysts for Reactions Involving Nitric Oxide," Applied Catalysis B: Environmental, Vol. 36, No. 4, 2002, pp. 287-297. doi:10.1016/S0926-3373(01)00286-7

[26] X. She and M. Flytzani-Stephanopoulos, "The Role of Ag-O-Al Species in Silver-Alumina Catalysts for the Selective Catalytic Reduction of $\mathrm{NO}_{x}$ with Methane," Journal of Catalysis, Vol. 237, No. 1, 2006, pp. 79-93. doi:10.1016/j.jcat.2005.09.036

[27] I. H. Son, M. C. Kim, H. L. Koh and K. L. Kim, "On the Promotion of $\mathrm{Ag} / \gamma-\mathrm{Al}_{2} \mathrm{O}_{3}$ by $\mathrm{Cs}$ for the SCR of NO by $\mathrm{C}_{3} \mathrm{H}_{6}$," Catalysis Letters, Vol. 75, No. 3-4, 2001, pp. 191-197. doi:10.1023/A:1016796022644

[28] R. Brosius, K. Arve, M. H. Groothaert and J. A. Martens, "Adsorption Chemistry of $\mathrm{NO}_{x}$ on $\mathrm{Ag} / \mathrm{Al}_{2} \mathrm{O}_{3}$ Catalyst for Selective Catalytic Reduction of $\mathrm{NO}_{x}$ Using Hydro Carbons," Journal of Catalysis, Vol. 231, No. 2, 2005, pp. 
344-353. doi:10.1016/j.jcat.2005.01.034

[29] M. Martinez-Arias, M. Fernández-García, A. IglesiasJuez, J. A. Anderson, J. C. Conesa and J. Soria, "Study of the Lean $\mathrm{NO}_{x}$ Reduction with $\mathrm{C}_{3} \mathrm{H}_{6}$ in the Presence of Water over Silver/Alumina Catalysts Prepared from Inverse Microemulsions," Applied Catalysis B: Environmental, Vol. 28, No. 1, 2000, pp. 29-41. doi:10.1016/S0926-3373(00)00160-0

[30] C. Bosch Ojeda and F. Sánchez Rojas, "Determination of
Rhodium: Since the Origins Until Today: ICP-OES and ICP-MS," Talanta, Vol. 71, No. 1, 2007, pp. 1-12. doi:10.1016/j.talanta.2006.04.024

[31] J. L. Hueso, J. Cotrino, A. Caballero, J. P. Espinós and A. R. González-Elipe, "Plasma Catalysis with PerovskiteType Catalysts for the Removal of $\mathrm{NO}$ and $\mathrm{CH}_{4}$ from Combustion Exhausts," Journal of Catalysis, Vol. 247, No. 2, 2007, pp. 288-297. doi:10.1016/i.jcat.2007.02.006 